\title{
IMPACT OF ENERGY CONSUMPTION AND CO 2 EMISSIONS ON FOOD PRODUCTION IN PAKISTAN: AN ECONOMETRIC ANALYSIS
}

\author{
Muhammad Akbar ${ }^{1, *}$, Farzana Noor ${ }^{1}$, Ishfaq Ahmad ${ }^{1}$ and A. Sattar \\ ${ }^{1}$ Department of Mathematics and Statistics, International Islamic University Islamabad, Pakistan \\ ${ }^{2}$ College of agriculture Bahadur Campus Layyah, Bahauddin Zakaria University Multan, Pakistan \\ "Corresponding author's e-mail: mmakbr@gmail.com
}

\begin{abstract}
Vision 2050 of UNO emphasizes doubling of world food production to achieve food security. Pakistan having $2.5 \%$ of the world population is food insecure country. It requires effective policies to meet the targets of UN Vision 2050. Analyzing the impact of some important factors of food production may be helpful to achieve sufficient food production in Pakistan. By using annual data from 1964 to 2015, this study estimates error correction model based upon ARDL co-integration technique to analyze dynamic impact of energy consumption and $\mathrm{CO}_{2}$ emissions along with other conventional inputs on food production in Pakistan. The study concludes short-run negative impact of energy consumption which is expected to be the price effect and, therefore, subsidized fuel price policy for framers is suggested. Environmental changes due to rising $\mathrm{CO}_{2}$ level are not adversely affecting food production as its estimates are significant with positive signs. Insignificance of physical capital and labor implies inefficient use of these inputs and a detailed analysis is recommended. Adverse impact of domestic credit induces revision of current policy regarding agricultural loans. Fertilizer off take shows positive impact whereas trade openness is insignificant for food production. Rising population shows negative impact on food production in Pakistan. Results of the study may be helpful for food policy makers in order to chase the Vision 2050.
\end{abstract}

Keywords: Food production, energy, environmental changes, domestic credit.

\section{INTRODUCTION}

Historically, Universal Declaration of Human Rights 1948 declared food security as basic human right. Since then, the issue of food security was focused by policy makers as well as academicians (Giraldo et al., 2008). Current comprehensive definition of food security is given as "All people, at all times, have physical, social and economic access to sufficient, safe and nutritious food that meets their dietary needs and food preferences for an active and healthy life" (FAO, 2010). This definition explains four dimensions of food security i.e. food availability, accessibility to food, utilization of food and stability of the three components. Research with respect to these four dimensions is being carried out all over the world at households' level as well as national level. FAO prediction about 2050 is that expected world population would be 9 billion which will require doubling of world food production (Rijsberman, 2012). An important question arises. Will the world be able to produce sufficient food in coming years? It may not be possible without proper planning at households' level and national level. Number of malnourished people has increased by more than 900 million around the world (FAO, 2009). Among these 900 million people, 800 million undernourished people are living in developing countries of Asia and Africa. A number of factors like drought, famines, climate changes, shortage or mismanagement of resources and growing population along with urbanization can be considered as causes for this high level of food insecurity in these developing countries.

In the context of national level food security, availability of food is considered as the basic component among the four dimensions. Food availability indicates a sufficient quantity of nutritious food which is available to all the individuals within a country or area through domestic output, level of food stocks and net food trade or food assistance (WFP, 2009). However, sufficient domestic food production is imperative to acquire food security in developing countries because of their limited resources for imports. Moreover, high population growth rates of these developing countries require continuous growth of food production of these countries to achieve global food security. That is the only way to chase Vision 2050 of UNO.

South Asian countries contain more than $25 \%$ of the world population. Developing economies of this region are agricultural based and hence, these countries must be selfsufficient in food supply. However, literature shows that all countries of south Asian region are food insecure (George, 1994; Timmer, 2000; Singh, 2002). Among these countries, Pakistan having about $2.5 \%$ of the world population, i.e. 210 million, is also facing the problem of food insecurity. Findings of Ahmed and Siddique (1995) are that high population growth, urbanization, income distribution, rising irrigation expenditures, and inadequate distributional system adversely affect food availability in Pakistan. Iram and Butt 
(2004) examined the main factors that are affecting food security at household level in Pakistan. The study proves that household income and environmental factors such as access to safe drinking water and improved sanitation facilities enhance absorption capacity of food intake. Hussain and Akram (2008) explored causes of declining food availability in Pakistan and effective policies for growth of food production are recommended. Ahmad (2009) analyzed food security situation of Pakistan by focusing domestic food production of wheat and rice. The study recommends financial support to small farmers, availability of inputs at affordable prices, control of wheat smuggling and adequate irrigation water supply by constructing dames in the country. Shahid and Siddiqui (2010) examined food security by taking Per capita food availability, economic access to food represented by the adult literacy rate and per capita income, and food absorption/utilization represented by the female literacy and infant mortality rate. It is concluded that overall food security situation in Pakistan is poor with respect to the three dimensions considered in the study. Mushtaq et al. (2011) analyzed some important macroeconomic policy variables as the determinants of wheat prices in Pakistan. The study concludes that macroeconomic policies may be handled to improve economic access to food in Pakistan. Determinants of food inflation are documented by Azeem et al. (2012) who explored positive impact of per capita income, negative impact of money supply and wheat support price on food prices in Pakistan. Using binary logistic regression, Bashir et al. (2012) explored significant and positive impact of education and income of households' heads on food security in Punjab. Akbar and Jamil (2012) estimated a model of agricultural sector of Pakistan. The study concludes through simulation analyses that rising energy prices, rising fertilizers' price and tight monetary policy adversely affect agricultural output in Pakistan. Hussain and Routray (2012) presented descriptive statistical analysis about food security in Pakistan and concludes that the average food consumption of its citizens is significantly lower than the standards of national food security line. Khan et al. (2012) examined rural food security situation of Pakistan and concludes that rural areas of only 40 districts out of 120 are food secure. Arshad and Shafqat (2012) mentioned that high population growth, poverty and inadequate health infrastructure adversely affect food security in Pakistan. According to Amir et al. (2013), water shortage for irrigation and inadequate access to markets are the major food production constraints in Northern Pakistan. Simulation analysis conducted by Akbar and Jabbar (2017) concluded that macroeconomic policies may be considered as effective tools to raise food production and to control food inflation in Pakistan. The study showed that average calorie supply per capita in Pakistan is low as compare to other developing world in spite of growth in agricultural production. It implies that domestic food production must be raised to achieve the status of self- sufficiency in Pakistan. Most of the studies related to food availability emphasize growth of agricultural output (Anderson, 2001; Singh, 2002; Kargbo, 2005; Hussain and Akram, 2008; Joel et al., 2012; Arshad and Shafqat, 2012; Akbar and Jamil, 2012; Akbar and Jabbar, 2017). Studies related to other countries show significant impact of climate changes and energy sector upon agricultural sector and food production (Tobey et al., 1992; Peng et al., 2004; Xiao et al., 2008; Wheeler and Braun, 2013; Ye et al., 2014). To the best of our knowledge, no such study is available in the literature of food security that has analyzed the impact of environmental changes on national food production in Pakistan. Hence, this study is conducted to analyze the impact of environmental changes due to $\mathrm{CO}_{2}$ emissions along with some other key inputs on food production in Pakistan. The rest of the paper consists of material and methodology, results and discussion and concluding remarks.

\section{MATERIALS AND METHODS}

Sufficient availability of food is the most important dimension of food security. Food supply in Pakistan mainly depends upon domestic food production due to limited resources for imports. Since focus of the study is domestic food production and, therefore, output of food crops $\left(\mathrm{FP}_{t}\right)$ is taken as the dependent variable. Cobb-Douglas production model has been followed by some of the studies for analyzing the impact of inputs on crop production (Singh et al., 2002; Yilmaz et al., 2005). Hence, Cob-Douglas production model is followed with four major inputs i.e. Physical Capital Stock in agricultural sector $\left(\mathrm{K}_{\mathrm{t}}^{\mathrm{A}}\right)$, labor employed in agricultural sector $\left(\mathrm{L}_{\mathrm{t}}{ }^{\mathrm{A}}\right)$ ), energy consumption in agricultural sector $\left(\mathrm{E}_{\mathrm{t}}{ }^{\mathrm{A}}\right)$ and fertilizers off take $\left(\mathrm{F}_{\mathrm{t}}{ }^{\mathrm{A}}\right)$. The model is extended by incorporating some other important determinants of food production. Food production takes place in a suitable environment as it helps interaction mechanism of inputs for output in agricultural sector. Hence, climate changes can have a decisive role in production of food crops. It may have beneficial or harmful effects on food production in a country. Variations in temperature along with precipitation patterns may threaten agricultural production. On the other hand, some empirical studies have proven positive effects of increased temperature in some parts of the world. Hence, $\mathrm{CO}_{2}$ emissions $\left(\mathrm{CO}_{\mathrm{t}}\right)$ are incorporated as explanatory variable in the model to analyze the impact of climate changes. Moreover, domestic credit to agricultural sector $\left(D_{t}\right)$ is also taken as an explanatory variable. Besides, total population $\left(\mathrm{N}_{\mathrm{t}}\right)$ and tradeopenness $\left(\mathrm{TO}_{\mathrm{t}}\right)$ representing demand side components are taken as control variables in the model. Hence the specified model is as follows.

$$
F P_{t}=f\left(K_{t}^{A}, L_{t}^{A}, E_{t}^{A}, F_{t}^{A}, C O_{t}, D C_{t}, T O_{t}, N_{t}\right)
$$

The study uses secondary annual data of all the variables covering the sample period from 1964 to 2015 with 2005-06 as the base year. Data sources are various issues of Pakistan 
Table 1. Results of Unit Root Tests.

\begin{tabular}{|c|c|c|c|c|c|c|}
\hline Varaibles & $\begin{array}{c}\text { ADF Statistic } \\
\text { at Level } \\
\text { (P Value) }\end{array}$ & $\begin{array}{c}\text { ADF Statistic at } \\
1^{\text {st }} \text { diff. } \\
\text { (P Value) }\end{array}$ & $\begin{array}{c}\text { PP Statistic at } \\
\text { Level } \\
\text { (P Value) }\end{array}$ & $\begin{array}{l}\text { PP Statistic } \\
\text { at } 1^{\text {st }} \text { diff. } \\
\text { (P Value) }\end{array}$ & $\begin{array}{c}\text { KPSS Stat. at } \\
\text { Level } \\
\text { (C.V. at 5\%) }\end{array}$ & $\begin{array}{l}\text { KPSS Stat. } \\
\text { at } 1^{\text {st }} \text { diff. } \\
(\text { C.V. at } 5 \%)\end{array}$ \\
\hline $\ln \left(\mathrm{FP}_{\mathrm{t}}\right)$ & $-1.0091(0.74)$ & $-6.3170(0.00)$ & $-0.2922(0.91)$ & $-4.0127(0.002)$ & $0.97(0.46)$ & $0.07(0.46)$ \\
\hline $\operatorname{Ln}\left(\mathrm{K}_{\mathrm{t}}^{\mathrm{A}}\right)$ & $-2.3114(0.17)$ & $-4.6504(0.00)$ & $-2.0200(0.28)$ & $-4.6100(0.00)$ & $0.78(0.46)$ & $0.45(0.46)$ \\
\hline $\operatorname{Ln}\left(\mathrm{L}_{\mathrm{t}}{ }^{\mathrm{A}}\right)$ & $0.2760(0.97)$ & $-5.9119(0.00)$ & $0.5344(0.98)$ & $-6.7035(0.00)$ & $0.93(0.46)$ & $0.13(0.46)$ \\
\hline $\operatorname{Ln}\left(F_{t}{ }^{A}\right)$ & $0.8092(0.99)$ & $-7.6743(0.00)$ & $1.5147(0.99)$ & $-10.5594(0.00)$ & $0.96(0.46)$ & $0.33(0.46)$ \\
\hline $\mathrm{Ln}\left(\mathrm{CO}_{\mathrm{t}}\right)$ & $-0.4714(0.88)$ & $-3.6902(0.00)$ & $-0.4865(0.88)$ & $-5.8587(0.00)$ & $0.95(0.46)$ & $0.15(0.46)$ \\
\hline $\operatorname{Ln}\left(\mathrm{E}_{\mathrm{t}}^{\mathrm{A}}\right)$ & $-1.3832(0.58)$ & $-8.6968(0.00)$ & $-1.3660(0.59)$ & $-8.5480(0.00)$ & $0.82(0.46)$ & $0.14(0.46)$ \\
\hline $\operatorname{Ln}\left(\mathrm{DC}_{\mathrm{t}}^{\mathrm{A}}\right)$ & $-1.0600(0.72)$ & $-8.0724(0.00)$ & $-1.0150(0.74)$ & $-8.0790(0.00)$ & $0.86(0.46)$ & $0.07(0.46)$ \\
\hline $\operatorname{Ln}\left(N_{t}\right)$ & $-4.035(0.002)$ & & $-3.7597(0.00)$ & & $0.24(0.14)$ & $0.09(0.14)$ \\
\hline $\mathrm{TO}_{\mathrm{t}}$ & $-2.5933(0.10)$ & $-8.9892(0.00)$ & $-2.5053(0.12)$ & $-9.2112(0.00)$ & $0.61(0.46)$ & $0.07(0.46)$ \\
\hline
\end{tabular}

Economic Survey and World Development Indicators (WDI). Variations in food output can be represented by food production per capita index given by WDI. It covers all food crops that are edible and include nutrients. Tea and coffee are not included in this index, although they are edible, but they do not have nutritive value. World Bank constructs food production index for many countries including Pakistan, so we have taken this index from WDI. Data of $\mathrm{CO}_{2}$ emissions in kiloton are also taken from WDI. Data regarding real private and public Gross Fixed Capital Formation in million rupees for agricultural sector, labor employed by agricultural sector in millions, energy consumption in agricultural sector, fertilizer off take in tons, domestic credit to agricultural sector in million rupees, imports and exports of goods and services in million rupees and total population in millions are taken from various issues of Pakistan Economic Survey. Perpetual inventory method is used to derive the data of physical capital stock of agricultural sector from the data of Gross Fixed Capital Formation in agricultural sector. Data of oil and petroleum consumption are available in tones. Data figures of electricity consumption, gas consumption and coal consumption are converted into tons of oil equivalent. Nominal values of domestic credit to agricultural sector are divided by GDP deflator to get real values of domestic credit. Total trade as percentage of GDP is taken as proxy for trade openness.

Selection of estimation technique depends upon order of integration of the time series variables. Three unit root tests are applied to test stationarity of all the variables. These tests include ADF test, PP test and KPSS test. Results of unit root tests (Table 1) show that integration order of the variables is mixture of $\mathrm{I}(0)$ and $\mathrm{I}(1)$. Hence, error correction model based on ARDL Cointegration (Bound testing) approach is followed to test cointegration and then error correction model is estimated. Bounds testing approach (Pesaran et al., 2001) has certain advantages over other cointegration techniques. Monte Carlo analysis proves superiority of the ARDL cointegration approach in small sample (Pesaran and Shin, 1999). As a first step, Cointegration is tested by estimating ARDL model. The following ARDL model is estimated for testing cointegration.

$$
\begin{aligned}
\Delta\left(\ln \left(F P_{t}\right)\right)= & \beta_{0}+\sum_{i=1}^{a_{1}} \beta_{1 i}\left(\Delta \ln \left(F P_{t-i}\right)\right)+\sum_{i=0}^{a 2} \beta_{2 i}\left(\Delta \ln \left(E_{t-i}^{A}\right)\right)+\sum_{i=0}^{a 3} \beta_{3 i}\left(\Delta \ln \left(C O_{t-1}\right)\right)+\sum_{i=0}^{a 4} \beta_{4 i}\left(\Delta \ln \left(K_{t-1}^{A}\right)\right)+ \\
& \sum_{i=0}^{a 5} \beta_{5 i}\left(\Delta \ln \left(L_{t-1}^{A}\right)\right)+\sum_{i=0}^{a 6} \beta_{6 i}\left(\Delta \ln \left(F_{t-i}^{A}\right)\right)+\sum_{i=0}^{a 7} \beta_{7 i}\left(\Delta \ln \left(D C_{t-i}^{A}\right)\right)+\alpha_{1} \ln \left(F P_{t-1}\right)+\alpha_{2} \ln \left(E_{t-1}^{A}\right) \\
& +\alpha_{3} \ln \left(C O_{t-1}\right)+\alpha_{4} \ln \left(K_{t-1}^{A}\right)+\alpha_{5} \ln \left(L_{t-1}^{A}\right)+\alpha_{6} \ln \left(F_{t-1}^{A}\right)+\alpha_{7} \ln \left(D C_{t-1}^{A}\right)+\varepsilon_{t}-------(1)
\end{aligned}
$$

Least square method is applied to estimate ARDL model (Eq. 1) by considering different lag lenghts and Wald F Statistic is employed to test $H_{0}=\alpha_{1}=\alpha_{2}=\alpha_{3}=\alpha_{4}=\alpha_{5}=\alpha_{6}=\alpha_{7}=0$ versus $H_{1} \neq \alpha_{1} \neq \alpha_{2} \neq \alpha_{3} \neq \alpha_{4} \neq \alpha_{5} \neq \alpha_{6} \neq \alpha_{7} \neq 0$. F Statistic is compared with upper and lower critical bounds given by Narayan (2005).

Error correction model is estimated in the second step provided cointegration exists. The following Error Correction Model is estimated.

$$
\begin{aligned}
\Delta \ln \left(F P_{t}\right)= & \lambda_{0}+\sum_{i=1}^{a} \lambda_{1 i} \Delta \ln \left(F P_{t-i}\right)+\sum_{i=0}^{a 2} \lambda_{2 i} \Delta \ln \left(E_{t-i}^{A}\right)+\sum_{i=0}^{a 3} \lambda_{3 i} \Delta \ln \left(C O_{t-1}\right)+\sum_{i=0}^{a 3} \lambda_{4 i} \Delta \ln \left(K_{t-1}^{A}\right) \\
& +\sum_{i=0}^{a 5} \lambda_{5 i} \Delta \ln \left(L_{t-1}^{A}\right)+\sum_{i=0}^{a 6} \lambda_{6 i} \Delta \ln \left(F_{t-1}^{A}\right)+\sum_{i=0}^{a 7} \lambda_{7 i} \Delta \ln \left(D C_{t-1}^{A}\right)+\beta_{8} \Delta(T O)_{t-1}+\beta_{9} \Delta(N)_{t-1} \\
& +\eta E C_{t-1}+v_{t}--------------------- \text { (2) }
\end{aligned}
$$

Here $\mathrm{EC}_{\mathrm{t}-1}$ is the error correction term derived from the corresponding long-run equilibrium relationship and $\eta$ is the adjustment factor of ECM. Various diagnostic tests are applied to establish validity of the estimated models. These tests include Lagranges Multiplier test, White test, ARCH test, Jarque-Bera test, Cusum test and Ramsey Reset test. EViews 10 is used to conduct analysis in this study.

\section{RESULTS AND DISCUSSION}

In order to test cointegrating relationship using ARDL technique, the first step is to decide optimal lag length on the basis of information criterion. VAR model is estimated taking the variables in natural logrithmic form and then lag length criterion are calculated. Different criterion show different optimal lag length varying from one to four (Table 2). Hence, we may test cointegration on the basis of different lag lenghts varying from one to four.

As a next step, ARDL model (Eq. 2) is estimated to test cointegration. 62500 ARDL equations are estimated on the basis of 4 maximum lag lengths. $\operatorname{ARDL}(3,2,2,1,0,4,4)$ is selected as the best model on the basis of Akaike Information Criterion. Results of diagnostic tests are presented in Table 3. 
Table 2. Results of Lag Length Criterion.

\begin{tabular}{lccllll}
\hline Lags & LogL & LR & FPE & AIC & SC & HQ \\
\hline 1 & 578.5661 & 395.11000 & $1.54 \mathrm{e}-18$ & -21.19025 & $-18.46142^{*}$ & -20.15902 \\
2 & 649.5495 & 91.68685 & $7.41 \mathrm{e}-19$ & -22.10623 & -17.46721 & -20.35314 \\
3 & 719.4127 & 69.86322 & $4.95 \mathrm{e}-19$ & -22.97553 & -16.42633 & -20.50058 \\
4 & 820.0229 & $71.26556^{*}$ & $1.60 \mathrm{e}-19 *$ & $-25.12595^{*}$ & -16.66657 & $-21.92914^{*}$ \\
\hline
\end{tabular}

* indicates lag order selected by the criterion

$\mathrm{R}^{2}$ and Adjusted $\mathrm{R}^{2}$ are more than $50 \%$ while JB test shows normality of residuals. Breusch-Godfrey LM test show that there is no serial correlation in the residual and White test establishes homoscedasticity. ARCH LM test shows that the equation does not contain ARCH effect. Figure 1 contains CUSUM test and the movement of cumulative sum of recursive residuals shows that the model's parameters and variance are stable. Wald F Statistic is 6.4425 whereas upper bound critical values for $\mathrm{k}=6$ and $\mathrm{n}=48$ are 3.62 at $5 \%$ and as 4.39 at $1 \%$ level of significance. F Statistic is sufficiently larger as compare to the upper bound critical values. Hence, null hypothesis of no cointegration is rejected. It implies that cointegrating relationship between food production and the specified explanatory variables exists.

After establishing cointegrating relationship, error correction model is estimated. Various error correction models are estimated while considering different lag lengths and then the best model is selected on the basis of significance of estimates. Long-run estimates and short-run estimates of the estimated model are presented in Table 4 and Table 5, respectively. Validity of estimated error correction model is established on the basis of diagnostic tests (Table 3). $\mathrm{R}^{2}$ is sufficiently high while JB test statistics shows normality of residuals. BG test statistic shows that residuals are free of autocorrelation whereas White test statistic establishes homoscedasticity of the model. ARCH LM test statistic shows that there is no ARCH effect in the estimated model. Ramsey Reset test shows correct specification of the model. CUSUM test (Fig. 2) shows that the estimated model is stable. Coefficient estimates of the ECM are interpreted as follows.

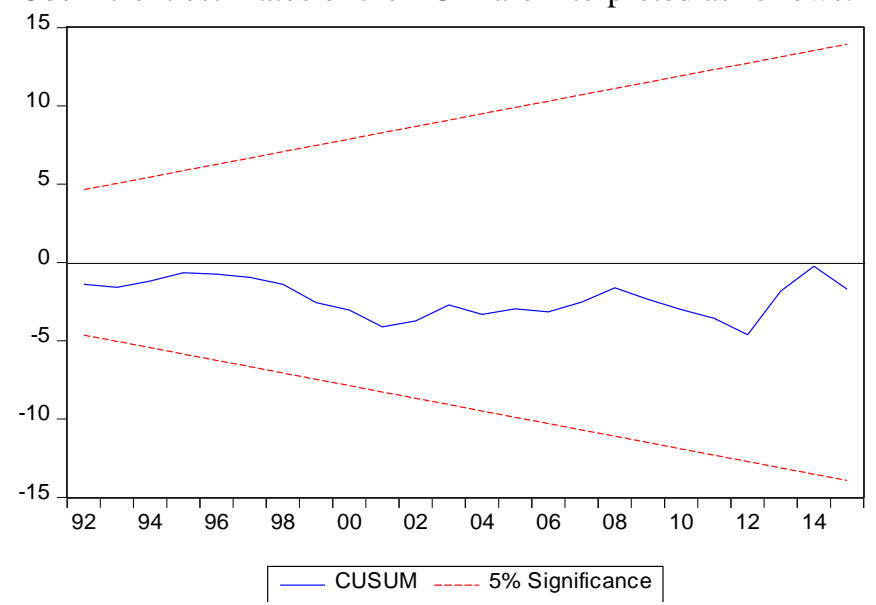

Figure 1. CUSUM test of ARDL Model.
Table 3. Results of Diagnostic Tests.

\begin{tabular}{lcc}
\hline Test Statistic & $\begin{array}{c}\text { Estimates with } \\
\text { (P value) }\end{array}$ & $\begin{array}{c}\text { Estimates with } \\
\text { (P Value) }\end{array}$ \\
\cline { 2 - 3 } & ARDL Eq. & ECM \\
\hline \multicolumn{1}{c}{ R-squared } & 0.9997 & 0.6019 \\
Adjusted R-squared & 0.9995 & 0.4380 \\
Jarque-Bera test & $1.7233:(0.42)$ & $2.2445:(0.3255)$ \\
statistics & & \\
BG Serial Correlation & $0.7766:(0.3873)$ & $0.0162:(0.8994)$ \\
White test (F-statistic) $)$ & $1.0637:(0.4400)$ & $0.8523:(0.6122)$ \\
ARCH test (F- & $1.0046:(0.3215)$ & $2.2635:(0.1160)$ \\
Statistic) & & \\
Ramsey RESET Test & $0.1707:(0.6833)$ & $0.4567:(0.5039)$ \\
\hline
\end{tabular}

Table 4. Long-run estimates of ECM.

\begin{tabular}{lrrrr}
\hline Regressors & Estimates & $\begin{array}{l}\text { Std. } \\
\text { Errors }\end{array}$ & t stat & $\begin{array}{c}\text { P } \\
\text { values }\end{array}$ \\
\hline Intercept & -3.0373 & 1.0009 & -3.0343 & 0.0040 \\
$l N\left(K_{t}^{A}\right)$ & 0.0913 & 0.1305 & 0.6999 & 0.4876 \\
$l N\left(L_{t}^{A}\right)$ & 0.5998 & 0.1353 & 4.4329 & 0.0001 \\
$l N\left(E_{t}^{A}\right)$ & 0.0214 & 0.0921 & 0.2332 & 0.8166 \\
$l N\left(F_{t}^{A}\right)$ & 0.0869 & 0.0273 & 3.1821 & 0.0027 \\
$l N\left(C O_{t}\right)$ & 0.3582 & 0.0596 & 6.0102 & 0.0000 \\
$l N\left(D C_{t}\right)$ & -0.0550 & 0.0231 & -2.3808 & 0.0216 \\
\hline
\end{tabular}

Table 5. Short-run Estimates of ECM.

\begin{tabular}{lccrc}
\hline Variable & Estimates & $\begin{array}{c}\text { Std. } \\
\text { Errors }\end{array}$ & t-Stat & $\begin{array}{c}\text { P. } \\
\text { Values }\end{array}$ \\
\hline$\Delta l N\left(F P_{t-1}\right)$ & 0.7663 & 0.1759 & 4.3547 & 0.0001 \\
$\Delta l N\left(F P_{t-2}\right)$ & -0.5051 & 0.1846 & -2.7359 & 0.0098 \\
$\Delta l N\left(K_{t}^{A}\right)$ & 0.0135 & 0.0503 & 0.2683 & 0.7901 \\
$\Delta l N\left(L_{t}^{A}\right)$ & 0.0403 & 0.0580 & 0.6958 & 0.4912 \\
$\Delta l N\left(L_{t-1}^{A}\right)$ & -0.1092 & 0.0791 & -1.3802 & 0.1765 \\
$\Delta l N\left(E_{t}^{A}\right)$ & -0.0553 & 0.0190 & -2.9044 & 0.0064 \\
$\Delta l N\left(F_{t}^{A}\right)$ & 0.0307 & 0.0130 & 2.3615 & 0.0241 \\
$\Delta l N\left(F_{t-1}^{\mathrm{A}}\right)$ & -0.0156 & 0.0128 & -1.2159 & 0.2324 \\
$\Delta l N\left(C O_{t}\right)$ & 0.0686 & 0.0299 & 2.2911 & 0.0283 \\
$\Delta l N\left(D C_{t}\right)$ & -0.0089 & 0.0058 & -1.5249 & 0.1365 \\
EC term & -0.1605 & 0.0432 & -3.7092 & 0.0007 \\
$\Delta\left(T O P_{t}\right)$ & 0.0003 & 0.0007 & 0.4469 & 0.6578 \\
$\Delta\left(N_{t}\right)$ & -0.0027 & 0.0010 & -2.7296 & 0.0100 \\
Intercept & 0.0309 & 0.0066 & 4.6697 & 0.0000 \\
TREND & 0.00003 & 0.0001 & 0.2304 & 0.8192 \\
\hline
\end{tabular}




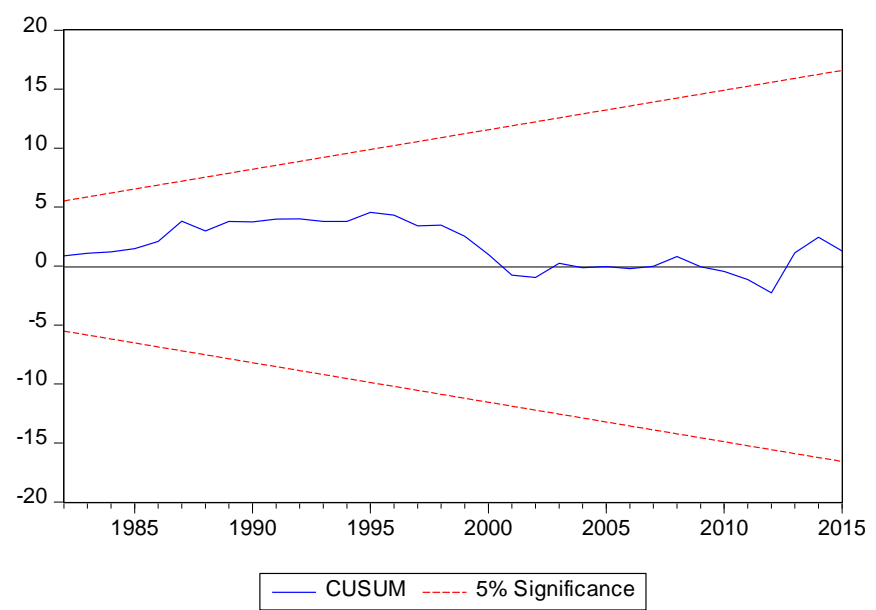

Figure 2. CUSUM test of ECM.

Most of the long-run estimates (Table 4) are significant. Moreover, error correction term of the model is significant and less than one with negative sign. It shows that estimated model represents long run stable relationship between food production and the explanatory variables. Estimate of adjustment coefficient is -0.1605 which implies that $16.05 \%$ short-run disequilibrium adjusts back to equilibrium in one year time period. Rest of the estimates may be explained as follows.

Estimates of physical capital stock in agricultural sector are insignificant in short-run as well as over long-run period of time. It implies that either there is inefficient use of investment or misallocation of resources in agricultural sector of Pakistan. It needs a thorough investigation of building of physical capital and its impact upon agricultural sector. However, an alarming trend can be pointed out that public investment in agricultural sector has been declining for the last two decades. This decline is of particular interest as public investment in basic infrastructure like canals, irrigation system, subsidies, improvement of lands, development of natural resources, training and research and development, are necessary conditions to obtain significant benefits from private investment. Moreover, domestic credit to agricultural sector is considered an important factor which helps farmers to build physical capital. However, its long-run estimate is significant with negative sign whereas short-run estimate is insignificant. It also shows misallocation of resources in the form of loans issued by Agricultural Development Bank of Pakistan. The reason may be that most of the creditors are landlords who do not use these loans for agricultural purpose. On the other hand, credit given to small farmers is accompanied by so strict conditions that it may not be useful for growth of their crops' output. However, insignificance of physical capital and domestic credit needs a thorough investigation of the policy.

Long-run estimate of energy consumption is insignificant whereas short-run estimate is significant with negative sign.
Short-run adverse impact of energy consumption may be justified due to rising prices of oil during the estimation sample period. Increase in energy prices raises cost of production which results into decline of output (Akbar and Jabbar, 2017). Since price effect of inputs may be considered only for short-run period and therefore, long-run impact of energy consumption on food production remains insignificant. Hence, subsidized rates of oil and electricity for agricultural sector especially for small landholding farmers may be helpful for growth of agricultural output. In most of the developing countries such as Pakistan, agriculture is transforming from conventional (low energy input) to mechanized (high energy input) agricultural production systems. Hence, food production needs energy for land preparation, cultivation, irrigation, harvesting, post-harvest processing, storage and the transport of agricultural inputs and outputs. It is, therefore necessary to fulfill the needs of energy demand of agricultural sector on subsidized rates like Indian government in order to raise food production in Pakistan.

Estimates of $\mathrm{CO}_{2}$ emissions show significant and positive impact on food production. It implies that rising $\mathrm{CO}_{2}$ level is enhancing food crops due to increasing productivity in natural ecosystem and water use efficiency of planets. Climate changes may have both types of positive as well as negative effects on food production. However, one type of effect may outweigh the other type of effects due to variations in temperature, precipitation and extreme climate events. Results of the study imply that positive effects of $\mathrm{CO}_{2}$ emissions are outweighing adverse impact of $\mathrm{CO}_{2}$ emissions in Pakistan. The results are not very surprising as literature contains empirical findings that the negative impacts of $\mathrm{CO}_{2}$ emissions reduce in the mid- and high-latitude areas. Increase in temperature due to $\mathrm{CO}_{2}$ emission might be a cause of declining growing span of crops and animals. Moreover, it causes melting of glaciers which irrigates more land and crops. However, heat stress events due to rising $\mathrm{CO}_{2}$ level must be expected as these events are a major cause of crop failure in summer. These results are in line with the literature of food security (Singh and Stewart, 1991; Maracchi et al., 2005; Tuck et al., 2006; Olesen et al., 2007; Battisti and Naylor, 2009).

Estimates of labor employed by agricultural sector shows positive and significant long-run impact on food production whereas short-run estimate is insignificant. Short-run insignificance of the estimate implies that the agricultural sector has no more demand of labor because farmers use more of capital equipment and depend less on labor. Quantity of fertilizers used by agricultural sector has positive and significant impact on food production. Some exogenous variables have also been included in the model. Trade openness is insignificant for food production while increase in population is badly affecting food production in Pakistan as cultivable land is being converted into residential areas. Moreover, as population increases, labor also increases and 
most of the uneducated labor enters into agricultural sector which have already excess of labor. These factors along with all other negative effects of high population growth cause adverse impact on food production in Pakistan.

Conclusion: This study analyzes the impact of energy consumption and environmental changes due to $\mathrm{CO}_{2}$ emissions along with conventional inputs on food production in Pakistan. Insignificance of physical capital stock may be considered an alarming situation. It implies that investment in agricultural sector is not being properly allocated or utilized. Moreover, there is drastic decline of public investment in agricultural sector which is considered as the backbone of basic infrastructure in the sector and, hence private investment also cannot perform well. Moreover, domestic credit to agricultural sector shows adverse impact on food production. Both of these results imply misallocation of resources in agricultural sector. Hence, a detailed investigation of agricultural investment and credit policy is recommended. Short-run insignificance of labor shows excess of labor in agricultural sector. Insignificance of long-run estimate and significant but adverse short-run impact of energy consumption on food production implies that high energy prices have negative impact on food production. It is therefore suggested that the government, like Indian government, may offer subsidized rates of oil and electricity for farmers in order to raise food production in Pakistan. Coefficient's estimates of $\mathrm{CO}_{2}$ emissions reveal positive impact which might be the result of shortening of growing span due to rise in temperature. The study concludes that rising $\mathrm{CO}_{2}$ emissions level is not threatening overall food production in Pakistan. However, detailed analysis regarding impact of rising temperature on summer food crops individually may be helpful to provide policy guidelines. Fertilizers off take is playing significant positive role in raising food production. Moreover, effects of foreign sector on food production are insignificant while population growth is adversely affecting food production and hence, effective policies of population planning are recommended in Pakistan. Recommendations of the study may be helpful for food policy makers to chaise the targets of UN Vision 2050.

\section{REFERENCES}

Ahmad, F. 2009. Food security in Pakistan. Pak. J. Agri. Sci. 46:83-89.

Ahmad, A. and S. Siddique. 1995. Food security in Pakistan: Can it be achieved. The Pak. Dev. Review 34:723-731.

Akbar, M. and F. Jamil. 2012. Monetary and fiscal policies' effect on agricultural growth: GMM estimation and simulation analysis. Econ. Model 29:1909-1920.

Akbar, M. and A. Jabbar. 2017. Impact of macroeconomic policies on national food security in Pakistan: Simulation analyses under a simultaneous equation framework. Agric. Econ. Czech. 63:471-484.

Amir, R.M., B. Shahbaz, T. Ali and M.I. Zafar. 2013. Analysis of household food security concerns and coping strategies of small farmers in north western highlands of Pakistan. Pak. J. Agri. Sci. 50:505-510.

Anderson, P. 2001. Appropriate technology for sustainable food security (No. 7). International Food Policy Research Institute (IFPRI).

Arshad, S. and A. Shafqat. 2012. Food security indicators, distribution and techniques for agriculture sustainability in Pakistan. Int. J. Appl. Sci. Tech. 2:137-147.

Azeem, M.M., S. Munawwar and K. Mushtaq. 2012. An empirical analysis of factors affecting food (wheat) inflation in Pakistan. Pak. J. Agri. Sci. 49:199-203.

Bashir, M.K., S. Schilizzi and R. Pandit. 2012. Are the determinants of food insecurity for landless households different from that of other rural households? Pak. J. Agri. Sci. 49:393-400.

Battisti, D.S. and R.L. Naylor. 2009. Historical warnings of future food insecurity with unprecedented seasonal heat. Sci. 323:240-244.

FAO. 2009. The state of food insecurity in the world: economic crises - impacts and lessons learned. UNO, Rome.

FAO. 2010. The state of food insecurity in the world: addressing food insecurity in protracted crises. UNO, Rome.

George, P.S. 1994. Food security in South Asia: Performance and prospects. Econ. Political Wkly. 29:1092-1094.

Giraldo, D.P., M.J. Betancur and S. Arango. 2008. Food security in development countries: A systemic perspective. Proc. Of 26th System Dynamics Conference. Athens, Greece.

Hussain, Z. and W. Akram. 2008. Persistent food insecurity from policy failures in Pakistan. Pak. Dev. Review 47:817-834.

Hussain, A. and J.K. Routray. 2012. Status and factors of food security in Pakistan. Int. J. Dev. Issues 11:164-185.

Iram, U. and M.S. Butt. 2004. Determinants of household food security: An empirical analysis for Pakistan. Int. J. Soc. Econ. 31:753-766.

Joel, A.J., K.G. Quentin and A.S. Oyekale. 2012. Subsistence farming and food security in cameroon: A macroeconomic approach. Life Sci. 9:3949-3954.

Kargbo, J.M. 2005. Impacts of monetary and macroeconomic factors on food prices in West Africa. Agrekon 44:205224.

Khan, R.E.A., T. Azid and M.U. Toseef. 2012. Determinants of food security in rural areas of Pakistan. Int. J. Soc. Econ. 39:951-964.

Maracchi, G., O. Sirotenko and M. Bindi. 2005. Impacts of present and future climate variability on agriculture and 
forestry in the temperate regions: Europe. In: Increasing Climate Variability and Change; pp.117-135.

Mushtaq, K., A. Ghafoor, Abedullah and A. Farhan. 2011. Impact of monetary and macroeconomic factors on wheat prices in Pakistan: Implications for food security. Lah. J. Econ. 16: 95-110.

Narayan, P.K. 2005. The saving and investment nexus for China: Evidence from cointegration tests. Appl. Econ. 37:1979-1990.

Olesen, J.E., T.R. Carter, C.H. Díaz-Ambrona and M. Quemada. 2007. Uncertainties in projected impacts of climate change on European agriculture and terrestrial ecosystems based on scenarios from regional climate models. Climatic Change 81:123-143.

Peng, S., J. Huang, J. Sheehy, R.C. Laza, R.M. Visperas, X. Zhong, G.S. Centeno, G.S. Khush and K.G. Cassman. 2004. Rice yields decline with higher night temperature from global warming. PNAS 101: 9971-9975.

Pesaran, M.H. and Y. Shin. 1999. An Autoregressive Distributed-led Modelling Approach to Cointegration Analysis. Cambridge University Press, Cambridge UK.

Pesaran, M.H., Y. Shin and R. J. Smith. 2001. Bounds testing approaches to the analysis of level relationships. J. Appl. Econ. 16: 289-326.

Rijsberman, F. 2012. CGIAR: A global research partnership for a food secure future. Available online at www.cgiar.org/consortium-news/cgiar

Singh, B. and R.B. Stewart. 1991. Potential impacts of a $\mathrm{CO}_{2-}$ induced climate change using the GISS scenario on agriculture in Quebec, Canada. Agric. Ecosyst. Environ. 35:327-347.
Singh, H., D. Mishra and N.M. Nahar. 2002. Energy use pattern in production agriculture of a typical village in arid zone India: Energ. Convers. Manage. 43:2275-2286.

Singh, S. 2002. Food security: Agenda for Asian economies. Econ. Polit. Wkly. 37:2418-2421.

Shahid, A. and M.W. Siddiqui. 2010. Food security analysis of Pakistan: Time series approach. Interdiscipl. J. Contemp. Res. Bus. 2:288-307.

Timmer, C.P. 2000. The macro dimensions of food security: Economic growth, equitable Distribution, and food price stability. Food Pol. 25:283-295.

Tobey, J., J. Reilly and S. Kane. 1992. Economic implication of global climate change for world agriculture. J. Agr. Resou. Econ. 17:195-204.

Tuck, G., M.J. Glendining, P. Smith, J.I. House and M. Wattenbach. 2006. The potential distribution of bioenergy crops in Europe under present and future climate. Biomass Bioenergy 30:183-197.

WFP. 2009. Emergency food security assessment handbook, $2^{\text {nd }}$ Ed. World Food Program, Rome.

Wheeler, T. and J.V. Braun. 2013. Climate change impacts on global food security. Sci. 341:508-513.

Xiao, G., Q. Zhang, Y. Yao, H. Zhao and R. Wang. 2008. Impact of recent climatic change on the yield of winter wheat at low and high altitudes in semi-arid northwestern China. Agr. Ecosyst. Environ. 127:37-42.

Ye, L., H. Tang, W. Wu, P. Yang, G.C. Nelson, D. MasonD'Croz and A. Palazzo. 2014. Chinese food security and climate change: Agriculture futures. Economics 8:1-39.

Yilmaz, I., H. Akcaoz and B. Ozkan. 2005. An analysis of energy use and output costs for cotton production in Turkey. Renew. Energy 30:145-155. 